\title{
MANAJEMEN PENGELOLAAN OBJEK WISATA BERBASIS TEKNOLOGI INFORMASI DI KABUPATEN JEMBRANA
}

\author{
Jimmy Harry Putu Suarthana ${ }^{1}$ \\ Ida Bagus Kade Dwi Suta Negara ${ }^{2}$ \\ STIPAR Triatma Jaya, Badung ${ }^{1}$ \\ Universitas Triatma Mulya, Jembrana² \\ email: jimmy.suarthana@triatmamulya.ac.id
}

\begin{abstract}
Tourism is one of the dominant income sectors for the island of Bali. Bali Island with a variety of tourist destinations spread across several regions, one of them is in Jembrana Regency. The lack of complete information makes several tourist destinations in Jembrana Regency not yet well known. By utilizing information technology, tourism managers can provide complete information to tourists and the public. The existence of this tourism object management system is expected to be one of the solutions in developing and promoting tourist destinations in Jembrana Regency so that it is better known and attracts the attention of tourists to visit. There are several facilities or features in this system including: data management, management of tourist objects, management of facilities, management of tourism events, and management of tourism promos. The results of user evaluations show that overall this system is good, but with this system some users expect that there will be additional features in this system.
\end{abstract}

Keywords: $\quad$ tourism, tourist destinations, information technology.

\section{PENDAHULUAN}

Sektor pariwisata adalah sektor yang potensial untuk dikembangkan sebagai salah satu sumber pendapatan daerah dan juga devisa bagi negara. Pariwisata merupakan salah satu sektor pendapatan yang sangat dominan untuk pulau Bali. Terutama kontribusinya dalam mendatangkan devisa, sehingga dapat menunjuang perekonomian di daerah tujuan wisata. Potensi dari tiap-tiap obyek wisata suatu daerah menjadi daya tarik tersendiri bagi pihak pengelola maupun pihak pemerintah daerah karena dapat digunakan sebagai sumber pendapatan daerah tersebut.

Pulau Bali memiliki berbagai destinasi wisata yang tersebar di beberapa daerah, salah satunya di Kabupaten Jembrana. Dalam hal ini
Kabupaten Jembrana memiliki beberapa potensi pariwisata seperti wisata alam, wisata budaya, wisata sejarah, dan wisata buatan. Kurangnya informasi yang lengkap membuat beberapa destinasi wisata yang ada di Kabupaten Jembrana belum begitu dikenal. Selain faktor informasi yang belum lengkap, faktor kondisi daerah juga menjadi salah satu penyebab belum dikembangkannya secara maksimal destinasi wisata di daerah tersebut.

Dengan teknologi informasi, pengelolaan destinasi wisata dapat diperkenalkan secara lebih luas dapat memberikan informasi destinasi wisata secara lengkap kepada wisatawan dan masyarakat yang ingin 
mengetahui destinasi wisata yang ada di sekitarnya.

Permasalahan yang terjadi selama ini adalah wisatawan sulit untuk mencari destinasi objek di Kabupaten Jembrana. Penelitian ini diarahkan pada pengelolaan objek/ destinasi wisata secara digital di wilayah Kabupaten Jembrana. Dengan adanya sistem informasi berbasis digital ini diharapkan menjadi salah satu solusi dalam mengembangkan dan mempromosikan destinasi wisata yang ada di Kabupaten Jembrana agar lebih dikenal dan menarik perhatian wisatawan untuk berkunjung. Teknologi sistem informasi ini juga merupakan solusi untuk menyebarkan informasi secara visual kepada calon wisatawan.

\section{TINJAUAN PUSTAKA}

\section{Pariwisata}

Pariwisata diidentikkan

dengan kata "travel" dalam bahasa Inggris yang diartikan sebagai perjalanan yang dilakukan berkali-kali darisatu tempat ke tempat lain atas dasar itu pula dengan melihat situasi dan kondisi saat ini pariwisata dapat diartikan sebagai suatu perjalanan terencana yang dilakukan secara individu atau kelompok dari satu tempat ke tempat lain dengan tujuan untuk mendapatkan kepuasan dan kesenangan [1].

Wisata adalah perjalanan yang dilakukan oleh seseorang atau kelompok orang, bersifat sementara, serta untuk menikmati objek dan atraksi di tempat tujuan [2].

Wisata memiliki karakteristik sebagai berikut:

1. Bersifat sementara, karena pelaku wisata hanya akan berada di tempat wisata dalam jangka waktu pendek, karena akan segera kembali ke tempat asalnya.

2. Melibatkan beberapa komponen wisata seperti sarana transportasi, akomodasi, objek wisata, dan lainlain.

3. Umumnya dilakukan dengan mengunjungi objek dengan atraksi wisata, daerah, atau bahkan negara secara terus-menerus.

4. Memiliki tujuan untuk mendapatkan kesenangan.

5. Tidak bertujuan untuk mencari nafkah, melainkan kedatangannya ke tempat tersebut dapat memberikan kontribusi pada pendapatan masyarakat atau daerah setempat.

6. Wisata terjadi karena adanya keterpaduan antara fasilitas dengan objek yang saling mendukung dan berkesinambungan.

Istilah wisata, seperti halnya yang tercantum dalam UU No. 10 tahun 2009, pengertian wisata diberikan batasan sebagai: kegiatan perjalanan yang dilakukan oleh seseorang atau sekelompok orang dengan mengunjungi tempat tertentu untuk tujuan rekreasi, pengembangan 7 pribadi, atau mempelajari keunikan daya tarik wisata yang dikunjungi dalam jangka waktu sementara [3].

Menurut Pitana destinasi adalah tempat yang dikunjungi dengan waktu yang signifikan selama perjalanan seseorang dibandingkan dengan tempat lain yang dilalui selama perjalanan (misalnya daerah transit) [4].

Jenis destinasi wisata adalah seperti berikut:

1. Destinasi sumber daya alam seperti iklim, pantai, hutan.

2. Destinasi sumber daya budaya seperti tempat bersejarah, museum, teater, dan masyarakat lokal. 
3. Fasilitas rekreasi seperti taman hiburan.

4. Event seperti Pesta Kesenian Bali, Pesta Danau Toba, pasar malam dan sebagainya.

\section{Teknologi Informasi}

Teknologi informasi adalah suatu teknik untuk mengumpulkan, menyiapkan, menyimpan, memproses, mengumumkan, menganalisis, dan menyebarkan informasi [5]. Teknologi informasi nyata menjadi tulang punggung kehidupan manusia. Kalau dahulu komputer dianggap hal yang mewah, namun sekarang boleh dikatakan siapa saja justru harus dapat memanfaatkan teknologi. Demikian dengan pesatnya teknologi yang ditandai dengan membanjirnya suatu informasi. Salah satu penerapan teknologi informasi yang menggelobal adalah jaringan internet. Melalui jaringan ini dapat dikatakan meniadakan jarak dan batas dalam penyebaran akses informasi. Disatu sisi ada pendapat bahwa melalui internet dapat diperoleh semua informasi yang diperlukan. Disisi lain hampir siapa saja baik perorangan ataupun lembaga berlomba menampilkan informasinya dalam internet. Sehingga dapat dipastikan tentu banyak juga informasi yang tidak benar di internet [6].

1) Istilah tekologi informasi (TI), sering dijumpai, baik dalam media grafik, seperti surat kabar dan majalah, maupun meda elektronik,seperti radio dan televisi. Istilah tersebut merupakan gabungan dua istilah dasar yaitu teknologi dan informasi. Teknologi dapat diartikan sebagai pelaksanaan ilmu, sinonim dengan ilmu terapan [7].

\section{METODE PENELITIAN}

Metode penelitian ini adalah mengikuti model pengembangan sistem yaitu SDLC (System Development Life Cycle). Proses pengembangan sistem ini dikenal dengan daur hidup pengembangan sistem yang memiliki beberapa tahapan. SDLC yang terkenal adalah model klasik yang biasa disebut dengan model waterfall.

$\begin{array}{llr} & \text { Adapun tahapan-tahapan } \\ \text { dalam pengembangan } & \text { sistem } \\ \text { menggunakan waterfall } & \text { adalah } \\ \text { sebagai berikut: } & & \end{array}$

\section{Analisis Kebutuhan}

Uji Coba

Pemeliharaan

Gambar 1

Metode Pengembangan Sistem menggunakan Waterfall 
Berikut ini adalah tahapan pengembangan sistem menggunakan waterfall:

1. Tahapan diawali dengan analisis kebutuhan terhadap permasalahan yang diangkat dalam hal ini adalah permasalahan tentang pengelolaan objek wisata di Kabupaten Jembrana. Analisis dilakukan dengan cara observasi langsung ke Dinas Pariwisata Kabupaten Jembrana.

2. Tahapan berikutnya adalah desain, pada tahap ini dilakukan desain dan perancangan terhadap sistem sebelum ke tahap pembuatan sistem.

3. Tahap pembangunan sistem, tahap ini adalah dilakukan dengan membuat kode-kode menggunakan bahasa pemrograman yang dapat dibaca oleh mesin atau dikenal dengan coding. Dalam penelitian ini, coding dibuat dengan menggunakan bahasa pemograman PHP, Java Script dan database MYSQL.

4. Pada tahap testing dilakukan dengan metode Black Box Testing. Black Box Testing memiliki sudut pandang luar dari objek tes untuk memperoleh masalah pada tes. Tes ini dapat memperoleh hasil sistem berfungsi atau tidak, apabila terjadi bugs dan error maka dapat dilakukan perawatan langsung terhadap sistem hingga kemungkinan bugs dan error tidak ditemukan lagi.

Pemeliharaan suatu sistem diperlukan, termasuk di dalamnya adalah pengembangan, karena software yang dibuat tidak selamanya hanya seperti itu. Ketika dijalankan mungkin saja masih ada errors kecil yang tidak ditemukan sebelumnya, atau ada penambahan fitur-fitur yang belum ada pada software tersebut. Pengembangan diperlukan ketika adanya perubahan dari eksternal perusahaan seperti ketika ada pergantian sistem operasi, atau perangkat lainnya.

\section{HASIL DAN PEMBAHASAN}

Pada hasil penelitian ini, penulis memberikan penjelaskan hasil dari penelitian yang dilakukan pada metodologi penelitian. Hasil tersebut akan dijelaskan secara terperinci dan jelas sebagai pembuktian dalam penelitian dan juga kedepannya dapat dikembangkan sebagai sistem yang nantinya dapat berguna bagi perusahaan. Berikut ini penjelasan dari hasil yang dilakukan pada penelitian ini:

\section{Analisis Kebutuhan}

Dari identifikasi permasalahan dan wawancara yang dilakukan pada bagian Observasi dan Wawancara, maka dapat dibuat gambaran kebutuhan pengguna sistem dengan menggunakan blok diagram sebagai berikut:

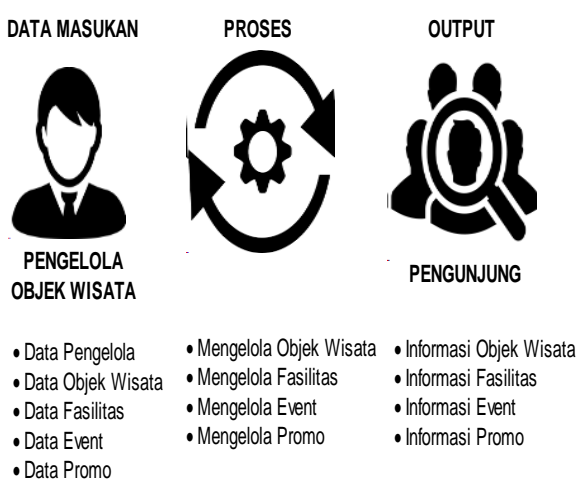

Gambar 2

Blok Diagram Analisis Kebutuhan

\section{Desain}

Desain dari sistem manajemen pengelolaan objek wisata ini 
Journal of Applied Management and Accounting Science (JAMAS)

(Jimmy Harry Putu Suarthana, Ida Bagus Kade Dwi Suta Negara 1 - 9) Vol 1, No 1, Desember 2019

menggunakan Data Flow Diagram $(D F D)$, yaitu sebagai berikut:

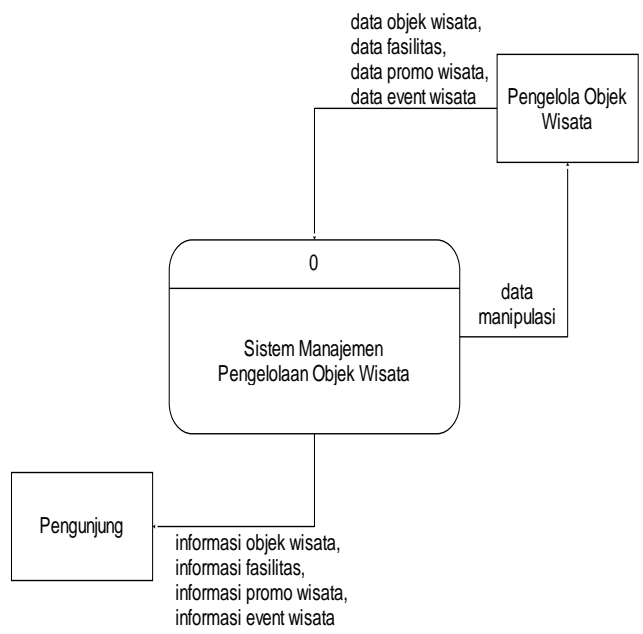

\section{Gambar 3}

Desain Sistem Menggunakan DFD

\section{Pembangunan Sistem}

Implementasi sistem didapat dari desain yang dibuat sebelumnya, berikut ini adalah beberapa hasil dari implementasi sistem:

a. Tampilan Login

Berikut ini adalah tampilan menu login pada sistem:

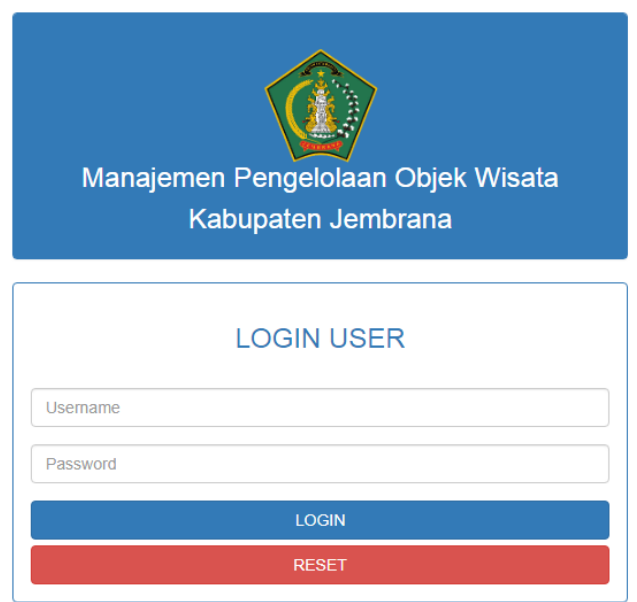

Gambar 4

Tampilan Login

Pada menu Login terdapat beberapa komponen yaitu: input untuk memasukkan username dan password, serta tombol Login.

b. Menu Utama Pengelola

Berikut ini adalah tampilan menu utama pengelola pada sistem:

(1. Sistem Pengelolaan Objek Wisata Kab. Jembrana

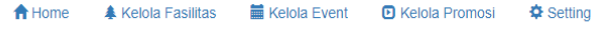

Selamat Datang Pengelola : Objek Wisata Gelar

\section{Gambar 5 Tampilan Menu Utama}

Pada menu Utama ini terdapat beberapa komponen menu yaitu: kelola fasilitas, kelola event, kelola promosi dan setting user.

\section{c. Menu Kelola Fasilitas}

Berikut ini adalah tampilan menu kelola fasilitas pada sistem:
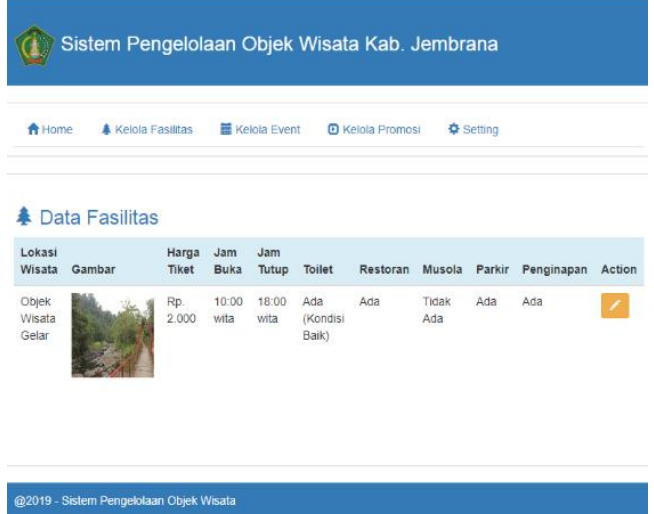

\section{Gambar 6}

Tampilan Menu Kelola Fasilitas

Pada menu kelola fasilitas ini terdapat menu untuk update nama 
lokasi wisata, gambar lokasi, harga masuk, jam buka, jam tutup, fasilitas seperti toilet, restoran, musola, parkir, dan penginapan.

\section{c. Menu Kelola Event}

Berikut ini adalah tampilan menu kelola event pada sistem:
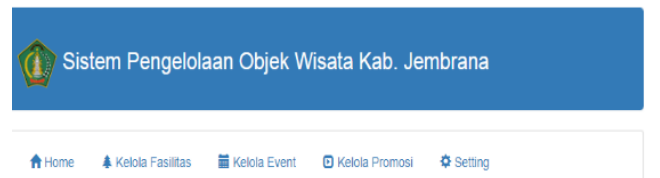

触 Data Event

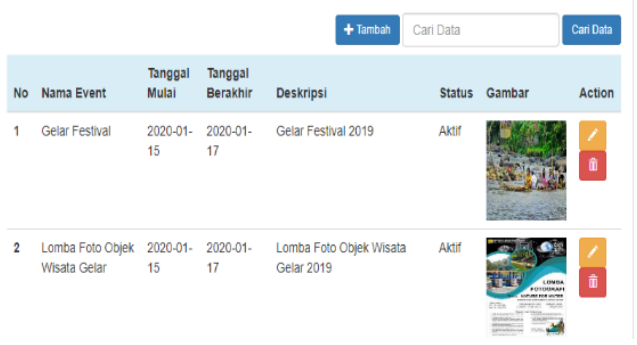

Gambar 7

Tampilan Menu Kelola Event

Pada menu kelola event ini terdapat menu input data event, update data event, dan hapus data event.

d. Menu Kelola Promo

Berikut ini adalah tampilan menu kelola promo pada sistem:

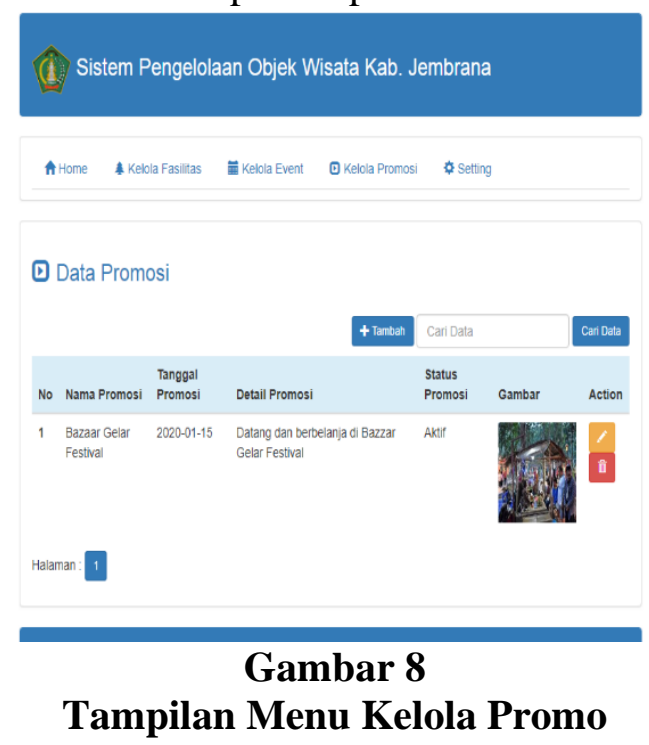

Pada menu kelola promo ini terdapat menu input data promo, update data promo, dan hapus data promo.

\section{e. Menu Setting User}

Berikut ini adalah tampilan menu setting user pada sistem:

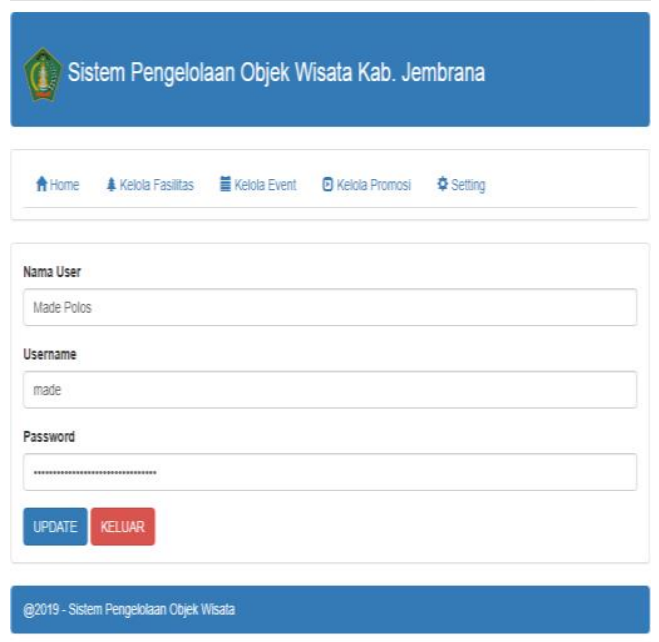

\section{Gambar 9}

Tampilan Menu Setting User

Pada menu setting user ini terdapat menu untuk update nama user, username, dan password.

\section{f. Halaman Website Objek Wisata}

Berikut ini adalah tampilan halaman website objek wisata kabupaten jembrana pada sistem:

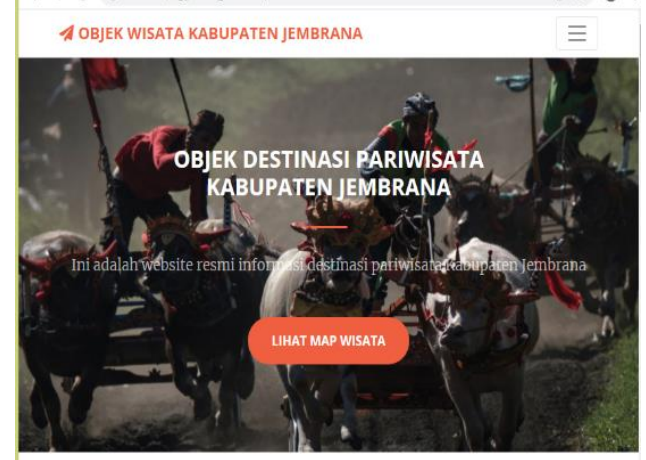


Journal of Applied Management and Accounting Science (JAMAS)

(Jimmy Harry Putu Suarthana, Ida Bagus Kade Dwi Suta Negara 1 - 9) Vol 1, No 1, Desember 2019

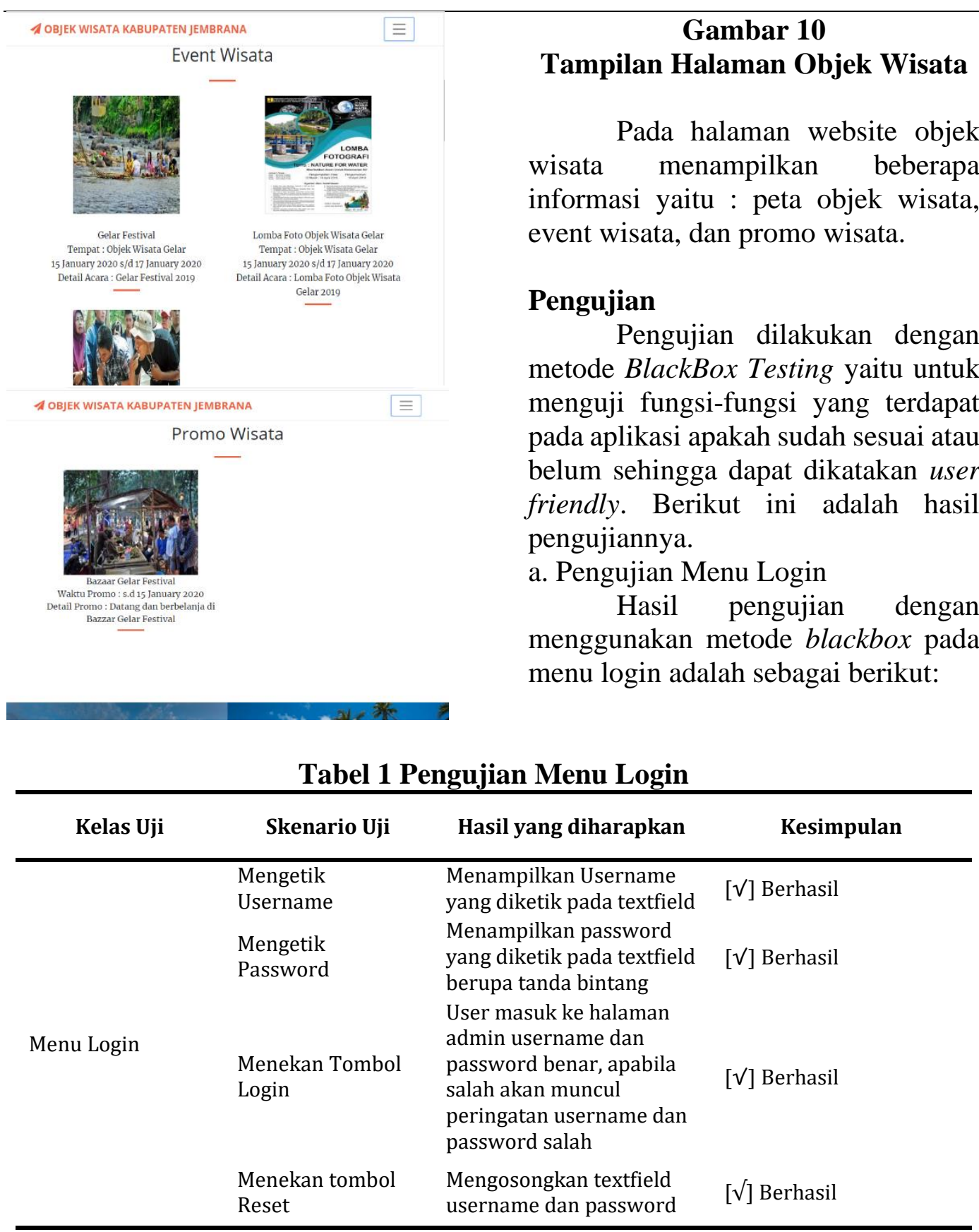

b. Pengujian Menu Utama

Hasil pengujian pada menu utama pengelola adalah sebagai berikut: 
Journal of Applied Management and Accounting Science (JAMAS)

(Jimmy Harry Putu Suarthana, Ida Bagus Kade Dwi Suta Negara 1 - 9) Vol 1, No 1, Desember 2019

\begin{tabular}{|c|c|c|c|}
\hline \multicolumn{4}{|c|}{ Tabel 2 Pengujian Menu Utama } \\
\hline Kelas Uji & Skenario Uji & Hasil yang diharapkan & Kesimpulan \\
\hline \multirow{4}{*}{$\begin{array}{l}\text { Halaman Utama } \\
\text { User Pengelola }\end{array}$} & $\begin{array}{l}\text { Menekan menu } \\
\text { Home }\end{array}$ & $\begin{array}{l}\text { Menampilkan halaman } \\
\text { home pengelola }\end{array}$ & {$[\sqrt{ }]$ Berhasil } \\
\hline & $\begin{array}{l}\text { Menekan menu } \\
\text { detail wisata }\end{array}$ & $\begin{array}{l}\text { Menampilkan drop down } \\
\text { menu fasilitas, event, dan } \\
\text { promosi }\end{array}$ & {$[\sqrt{ }]$ Berhasil } \\
\hline & $\begin{array}{l}\text { Menekan menu } \\
\text { pelaporan }\end{array}$ & $\begin{array}{l}\text { Menampilkan drop down } \\
\text { menu pelaporan pengunjung } \\
\text { dan pelaporan event }\end{array}$ & {$[\sqrt{ }]$ Berhasil } \\
\hline & $\begin{array}{l}\text { Menekan menu } \\
\text { peta wisata }\end{array}$ & $\begin{array}{l}\text { Menampilkan peta lokasi } \\
\text { wisata }\end{array}$ & {$[\sqrt{ }]$ Berhasil } \\
\hline
\end{tabular}

\section{c. Pengujian Menu Kelola Fasilitas}

Hasil pengujian pada menu

kelola fasilitas wisata adalah sebagai berikut:

Tabel 3 Pengujian Menu Fasilitas

\begin{tabular}{cccc}
\hline Kelas Uji & Skenario Uji & Hasil yang diharapkan & Kesimpulan \\
\hline $\begin{array}{c}\text { Halaman } \\
\text { Fasilitas } \\
\text { Wisata }\end{array}$ & $\begin{array}{c}\text { Menampilkan tabel } \\
\text { Menekan Tombol Action } \\
\text { Update }\end{array}$ & $\begin{array}{c}\text { Tampil detail fasilitas } \\
\text { wisata }\end{array}$ & $\begin{array}{c}\text { Tampil form update } \\
\text { fasilitas wisata }\end{array}$ \\
\hline
\end{tabular}

\section{d. Pengujian Menu Kelola Event}

Hasil pengujian pada menu

kelola event wisata adalah sebagai

berikut:

Tabel 4 Pengujian Menu Event

\begin{tabular}{|c|c|c|c|}
\hline Kelas Uji & Skenario Uji & $\begin{array}{c}\text { Hasil yang } \\
\text { diharapkan }\end{array}$ & Kesimpulan \\
\hline \multirow{5}{*}{$\begin{array}{l}\text { Halaman } \\
\text { Event } \\
\text { Wisata }\end{array}$} & $\begin{array}{c}\text { Menekan Tombol Tambah } \\
\text { event }\end{array}$ & $\begin{array}{c}\text { Tampil form inputan } \\
\text { data event }\end{array}$ & {$[\sqrt{ }]$ Berhasil } \\
\hline & Menampilkan tabel list event & $\begin{array}{c}\text { Tampil list tabel } \\
\text { event }\end{array}$ & {$[\sqrt{ }]$ Berhasil } \\
\hline & $\begin{array}{c}\text { Menekan Tombol Action } \\
\text { Update }\end{array}$ & $\begin{array}{l}\text { Tampil form update } \\
\text { event }\end{array}$ & {$[\sqrt{ }]$ Berhasil } \\
\hline & $\begin{array}{c}\text { Menekan Tombol Action } \\
\text { Delete }\end{array}$ & $\begin{array}{c}\text { Tampil form delete } \\
\text { event }\end{array}$ & {$[\sqrt{ }]$ Berhasil } \\
\hline & Menekan Tombol Cari & $\begin{array}{c}\text { Menampilkan hasil } \\
\text { pencarian tabel } \\
\text { event }\end{array}$ & {$[\sqrt{ }]$ Berhasil } \\
\hline
\end{tabular}

d. Pengujian Menu Kelola Promo

Hasil pengujian pada menu kelola

promo wisata adalah sebagai berikut: 
Journal of Applied Management and Accounting Science (JAMAS)

(Jimmy Harry Putu Suarthana, Ida Bagus Kade Dwi Suta Negara 1 - 9) Vol 1, No 1, Desember 2019

\begin{tabular}{|c|c|c|c|}
\hline \multicolumn{4}{|c|}{ Tabel 4 Pengujian Menu Promo } \\
\hline Kelas Uji & Skenario Uji & $\begin{array}{c}\text { Hasil yang } \\
\text { diharapkan }\end{array}$ & Kesimpulan \\
\hline \multirow{5}{*}{$\begin{array}{l}\text { Halaman } \\
\text { Promosi Wisata }\end{array}$} & $\begin{array}{l}\text { Menekan Tombol Tambah } \\
\text { promosi }\end{array}$ & $\begin{array}{l}\text { Tampil form inputan } \\
\text { data promosi }\end{array}$ & {$[\sqrt{ }]$ Berhasil } \\
\hline & $\begin{array}{l}\text { Menampilkan tabel list } \\
\text { promosi }\end{array}$ & $\begin{array}{l}\text { Tampil list tabel } \\
\text { promosi }\end{array}$ & {$[\sqrt{ }]$ Berhasil } \\
\hline & $\begin{array}{l}\text { Menekan Tombol Action } \\
\text { Update }\end{array}$ & $\begin{array}{l}\text { Tampil form update } \\
\text { promosi }\end{array}$ & {$[\sqrt{ }]$ Berhasil } \\
\hline & $\begin{array}{l}\text { Menekan Tombol Action } \\
\text { Delete }\end{array}$ & $\begin{array}{l}\text { Tampil form delete } \\
\text { promosi }\end{array}$ & {$[\sqrt{ }]$ Berhasil } \\
\hline & Menekan Tombol Cari & $\begin{array}{l}\text { Menampilkan hasil } \\
\text { pencarian tabel } \\
\text { promosi }\end{array}$ & {$[\sqrt{ }]$ Berhasil } \\
\hline
\end{tabular}

\section{SIMPULAN DAN SARAN \\ Simpulan}

Berdasarkan hasil pembahasan pengembangan sistem pengelolaan objek wisata berbasis teknologi informasi di Kabupaten Jembrana ini, adapun kesimpulannya sebagai berikut:

1. Terdapat beberapa fasilitas atau fitur dalam sistem ini meliputi: pengelolaan objek wisata, fasilitas wisata, event wisata, dan promo wisata.

2. Hasil pengujian menunjukkan bahwa semua menu dapat bekerja sebagaimana mestinya.

\section{Saran}

Untuk pengembangan lebih lanjut, adapun saran-saran yang dapat penulis sampaikan adalah sistem ini sebaiknya dilakukan pemeliharaan berkala untuk menjaga dan memaksimalkan fungsi kebutuhan dan informasi yang dibutuhkan pengelola objek wisata dan pengunjung.

\section{DAFTAR PUSTAKA}

Arikunto, S. 2002. Prosedur S. Sinaga, "Potensi dan Pengembangan Objek Wisata Di Kabupaten Tapanuli Tengah," 2010.
Suyitno, Perencanaan Wisata. Yogyakarta: Kanisius, 2006.

P. R. Indonesia, Undang-undang No. 10 Tahun 2009 tentang Kepariwisataan. 2009.

I. G. Pitana, Pengantar Ilmu Pariwisata. Yogyakarta:

Penerbit Andi, 2009.

UU RI No 11 Tahun 2008 Informasi Dan Transaksi Elektronik, (Jakarta: Sinar Grafika, 2010), h.3. 32Blasius

Sudarsono, Pustakawan Cinta Dan Teknologi, ( Jakarta : Ikatan Sarjan Ilmu Perpustakaan Dan Informasi Indonesia, 2009 ), h. 37

I Putu Agus Eka Pratama, Sistem Informasi Dan Inmplementasinya : Teori Dan Konsep Sistem Informasi Disertai Berbagai Contoh Praktiknya Perangkat Lunak Oper Source, (Bandung : Informatika, 2014), h.8-9 